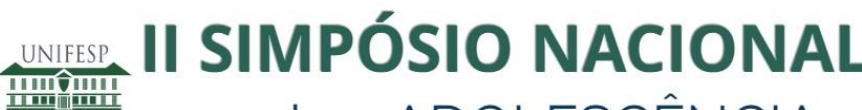 sobre ADOLESCÊNCIA: Vulnerabilidades, Protagonismos e Desafios
}

\section{Adolescer no território: os desafios do empoderamento ante as vulnerabilidades}

Gabriela Alves Martins Guimarães Lyrio Todo
Ailton de Souza Aragão
Rosimár Alves Querino
Ana Elisa Crispim
Luciana Trajano da Silva
Fernanda Sousa Bastos de Moraes
Maria Carollina Vieira Cardoso
Leticia Caroline Buscaratti
Mellany Vieira
Talita Cristina Grizólio
Natália de Toledo Cadore
Otávio Loyola Martins
Maria Lopes da Silva

\section{Como citar:}

TODO, Gabriela Alves Martins Guimarães Lyrio et al. Adolescer no território: os desafios do empoderamento ante as vulnerabilidades. In: SIMPÓSIO NACIONAL SOBRE ADOLESCÊNCIA: VULNERABILIDADE, PROTAGONISMOS E DESAFIOS, 2, 2016, São Paulo. Anais...[S. I.]: 2016. p. 46-47. DOI: http://dx.doi.org/10.22388/2525-5894.2016.025

Introdução: o fenômeno da redução da idade penal tem sido frequentemente tratado de modo reducionista pela mídia e pelo senso comum. Em discussões rasas, observa-se o descarte dos direitos conquistados com o Estatuto da Criança e do Adolescente (1990) em detrimento de uma propalada segurança. O Art. 227. da Constituição Federal de 1988, pontua o dever da família, da sociedade e do Estado em assegurar à criança, ao adolescente e ao jovem, com absoluta prioridade, o direito à vida, à saúde, à alimentação, à educação, ao lazer, à profissionalização, à cultura, à dignidade, ao respeito, à liberdade e à convivência familiar e comunitária, além de colocá-los a salvo de toda forma de negligência, discriminação, exploração, violência, crueldade e opressão (Redação dada pela Emenda Constitucional no 65, de 2010). Verifica-se que em termos legislativos, o Brasil superou limitações consistentes que na prática, infelizmente, deixam muito a desejar. Os direitos de crianças e adolescentes historicamente vulnerados são negligenciados, logo, uma vulnerabilidade programática. Inúmeras crianças presenciam privações de seus direitos básicos; muitas vivenciam violências cotidianamente. A ausência ou precarização de equipamentos públicos para efetivar os direitos acima descritos favorecem a exposição a ambientes violentos e potencializam os riscos. O projeto Adolescer no território ocorre em solos mineiros, em uma cidade de médio porte, com grupos de adolescentes em situação de vulnerabilidade e que são acompanhadas pelos Centros de Referência e Assistência Social (CRAS) e esses adolescentes integram os 
Coletivos do ProJovem. Nesse sentido, em cenários do Adolescer, urge a necessidade da construção de linhas de debate que valorizem a complexidade do tema e de seus determinantes aliada à necessidade da adoção de postura interdisciplinar.

Objetivos: analisar a compreensão dos adolescentes em situação de vulnerabilidade social acerca de seus Direitos Fundamentais e verificar como os debates em torno dos direitos humanos potencializam o empoderamento dos mesmos.

Metodologia: projeto Extensão "Adolescer no Território" com interface em Pesquisa qualitativa norteada pelos pressupostos da promoção da saúde desenvolvidas de modo lúdico (teatro, dinâmicas de grupo e jogos), com 10 adolescentes participantes do projeto no ano de 2015 e 2016 em um dos 8 CRAS em uma cidade de médio porte do Triângulo Mineiro. O método de pesquisa adotado foi o Grupo Focal com a questão norteadora: "direitos dos adolescentes - o que sei?". Após a obtenção do consentimento dos pais/responsáveis, gravamos o áudio do Grupo, transcrevemos e analisamos os depoimentos na modalidade de conteúdo temático.

Resultados: as categorias temáticas que emergiram do Grupo foram Proteção integral e Desigualdade étnico-social. A primeira categoria demonstra que a proteção integral não lhes diz respeito, não a reconhecem e tampouco se reconhecem como portadores desse direito, restringindo-se "aos filhos dos ricos", os quais "podem pagar" pela proteção. Traço patente ao se referirem aos serviços de saúde. Em segundo lugar, mas não menos importante, a desigualdade social aliada ao componente étnico reforça a condição social de vulnerável ao risco da violência gerada pelo tráfico de drogas e ou pela ostensão policial. Logo, ser "negro" e "pobre" os afasta da efetividade dos direitos, que são deles.

Conclusões e limitações: os adolescentes retratam a desigualdade de acesso e a efetivação dos direitos a partir da desigualdade de renda e a conservação de uma realidade como intocável, naturalizando-a, pois não se efetiva nos territórios vividos. Promover direitos protetivos é promover, portanto, possibilidades de enfrentamento coletivo às condições de vida. Contudo, diante de um fenômeno complexo, demanda interações interdisciplinares e multiprofissionais em conjunto com os adolescentes, como forma de avaliação crítica das políticas públicas em vigor no Brasil destinadas a esse segmento demográfico. Trata-se de uma atividade extensionista com interface em pesquisa, portanto, realizada com alguns cortes temporais; as atividades realizadas nos CRAS's obedecem à dinâmica institucional. Esses fatores desafiam a continuidade e o fortalecimento dos vínculos entre as extensionistas e os adolescentes.

Palavras-chaves: Direitos fundamentais. Vulnerabilidade. Desigualdade social. Empoderamento. 